JURNAL Penelitian Hasil Hutan Vol. 37 No. 2, Juli 2019: 105-122

p-ISSN: 0216-4329

e-ISSN: 2442-8957

Terakreditasi Peringkat 2, No: 21/E/KPT/2018

\title{
PEMANFAATAN CAMPURAN ARANG AKTIF KAYU Muntingia calabura L. DAN BAKTERI Escherichia coli PADA PENGOLAHAN LIMBAH KROMIUM INDUSTRI ELEKTROPLATING* (Utilization of the Combination of Muntingia calabura $\underline{L}$. Wood Activated Charcoal and Escherichia coli Bacteria for Chromium Waste Handling in Electroplating Industry)
}

\author{
Endang Sri Lestari ${ }^{*}$, Yusuf Sudo $\mathrm{Hadi}^{2}$, \& Gustan Pari ${ }^{3}$ \\ ${ }^{1}$ Politeknik AKA, Jl. Pangeran Sogiri No. 283, Bogor 16154, Telp. (0251) 8650351 \\ ${ }^{2}$ Institut Pertanian Bogor, Jl. Lingkar Akademik Kampus IPB, Bogor 16680. Telp (0251) 8621677 \\ ${ }^{3}$ Pusat Penelitian dan Pengembangan Hasil Hutan, Jl. Gunung Batu 5 Bogor 16610, Telp. (0251)8633378 \\ *E-mail: lestarirahadian@ymail.com
}

Diterima 06 September 2017, direvisi 10 Januari 2019, disetujui 8 Juli 2019

\begin{abstract}
The presence of heavy metal chromium wasted from electroplating industry could harm buman health, such as posing cancer and kidney failure. In order to overcome this problem, the effluent treatment was carried out by means of adsorption of chromium using wood activated charcoal. This paper aims to study the benefits of Muntingia calabura wood activated charcoal, especially seeking its optimal conditions for adsorption test and the ability of Escherichia coli bacteria to turn out chromium (VI) biodegradation into chromium (III) on chromium waste of electroplating industry. Wooden charcoal was produced after heating wood at $500^{\circ} \mathrm{C}$ for an hour and it was activated using hot water vapor at $800^{\circ} \mathrm{C}$ for 70 minutes and pressure $120 \mathrm{mBar}$. The adsorption test was conducted in variation of $20-100 \mathrm{mg} / \mathrm{L}$ of adsorbate initial concentration, contact time 45-105 minutes, and stirring speed of 100-300 rpm. Biodegradation test was conducted using Escherichia coli bacteria which was incubated in nutrient broth containing of adsorption waste. Results showed that the optimal conditions of the adsorption test was recorded at the initial concentration of $70 \mathrm{mg} / \mathrm{L}, 150 \mathrm{rpm}$ stirring speed, 75 minutes contact time, and 86.7\% adsorption effectivity. The biodegradation effectivity for turning chromium (VI) into chromium (III) was recorded at $98.6 \%$.
\end{abstract}

Keywords : Adsorption, Muntingia calabura, wood, chromium, biodegradation

\begin{abstract}
ABSTRAK
Keberadaan logam berat krom dari limbah industri elektroplating dapat membahayakan kesehatan manusia, di antaranya menyebabkan kanker dan gagal ginjal. Untuk mengatasi masalah ini, dilakukan upaya pengolahan limbah dengan cara adsorpsi menggunakan arang aktif dari kayu. Tulisan ini mempelajari kondisi optimal uji adsorpsi arang aktif kayu Muntingia calabura dan kemampuan bakteri Escherichia coli melakukan biodegradasi krom (VI) menjadi krom (III) pada pengolahan limbah krom industri elektroplating. Arang kayu dibuat pada suhu $500^{\circ} \mathrm{C}$ selama 1 jam dan diaktivasi dengan uap air panas pada suhu $800^{\circ} \mathrm{C}$ pada variasi waktu kontak 70-110 menit dengan tekanan 120 dan 150 mBar. Uji adsorpsi dilakukan dengan variasi konsentrasi awal adsorbat 20-100 mg/L, waktu kontak 45-105 menit, dan kecepatan pengadukan 100-300 rpm. Uji biodegradasi menggunakan bakteri Escherichia coli yang diinkubasi di dalam nutrient broth yang mengandung limbah hasil adsorpsi. Hasil penelitian memperlihatkan bahwa kondisi optimal uji adsorpsi adalah konsentrasi awal $70 \mathrm{mg} / \mathrm{L}$, kecepatan pengadukan $150 \mathrm{rpm}$ dan waktu kontak pada 75 menit, dengan efektivitas sebesar 86,7\%. Efektifitas biodegradasi krom (VI) menjadi krom (III) adalah 98,6\%.
\end{abstract}

Kata kunci: Adsorpsi, Muntingia calabura, krom, biodegradasi

\footnotetext{
* Naskah merupakan bagian dari tesis mahasiswa Program Magister (S-2) pada Program Studi Pengelolaan Sumberdaya Alam dan Lingkungan, Institut Pertanian Bogor, Bogor
} 


\section{PENDAHULUAN}

Meningkatnya kebutuhan masyarakat akan produk tahan karat mendorong meningkatnya perkembangan industri elektroplating. Perkembangan industri ini selain memberikan manfaat juga menimbulkan dampak negatif dari limbah yang dihasilkan, karena mengandung logam berat di antaranya krom. Keberadaan krom dalam perairan tidak mudah terdegradasi dan dapat terdistribusi ke bagian tubuh manusia, hewan, dan tumbuhan dan dapat mencapai besaran yang membahayakan kesehatan manusia (Bernard et al., 2013). Burg dan Liu (1993) melaporkan, bahwa krom termasuk logam yang memiliki toksisitas tinggi, terutama dalam bentuk krom heksavalen yang bersifat karsinogenik. Limbah logam berat krom dapat menyebabkan kerusakan hati, ginjal, dan saluran pernafasan, pendarahan dalam tubuh, dermatitis, dan kanker paru-paru.

Berdasarkan bahaya yang ditimbulkan, maka diperlukan penanganan serius, mengingat air sungai merupakan sumber utama kegiatan pertanian, perikanan, bahkan di beberapa kota besar dapat merupakan sumber air minum. Menurut Laksono (2009), salah satu alternatif cara penanganan limbah adalah menggunakan adsorben sebagai pengikat atau pengadsorp limbah berbahaya, yaitu logam dan molekul organik yang tidak mudah terdegradasi. Bahan alam atau limbah pertanian merupakan adsorben yang menarik dikaji, karena potensinya yang cukup baik jika dilihat dari efektivitas, komposisi kimia, dan struktur komponen yang terkandung di dalamnya, serta ramah lingkungan, salah satunya adalah kayu dari tanaman kersen (Muntingia calabura L.) yang merupakan spesies tunggal dalam genus Muntingia. Kersen yang mempunyai nama lain di antaranya ceri (Sunda), atau talok (Jawa) adalah spesies pionir berdaun hijau yang dapat tumbuh lebih baik dibandingkan tanaman lain di tanah yang tandus (Birasal, 2013). Tanaman kersen mampu mentolerir asam, basa dan kondisi kekeringan, tetapi tidak toleran terhadap garam (Morton, 1987).

Proses aktivasi untuk mendapatkan arang aktif yang bersifat amorf dan berpori, menurut Pari (2004) dapat dilakukan dalam dua tahap yaitu dilakukan pada suhu rendah dan suhu tinggi. Proses aktivasi dilakukan untuk menghilangkan hidrokarbon yang melapisi permukaan arang, sehingga meningkatkan porositas arang kayu. Salah satu metode pembuatan arang aktif dilakukan dengan cara fisika yaitu mengalirkan uap air. Reaksi aktivasi berjalan secara endotermis, sehingga proses aktivasinya kurang efektif. Salah satu cara untuk meningkatkan efektivitas aktivasi arang adalah dengan memanaskan permukaan luar dari unit aktivasinya, sehingga distribusi panasnya lebih merata dan aktivasi lebih efektif.

Sifat toksik logam berat krom (VI) jauh lebih toksik dibandingkan krom (III). Berdasarkan Permen Lingkungan Hidup No. 5 tahun 2014, kadar maksimum krom total yang diperbolehkan dalam perairan adalah $0,5 \mathrm{mg} / \mathrm{L}$, sedangkan kadar krom (VI) 0,1 mg/L (Kementerian Lingkungan Hidup, 2014). Hal ini menunjukkan, bahwa dalam jumlah yang sangat sedikit, krom (VI) telah dapat menyebabkan masalah bagi lingkungan. Bakteri perairan air tawar khususnya Escherichia coli dalam keadaantertentudapatmelakukan reaksienzimatik yang dapat mengkatalisis terjadinya transformasi krom (VI) yang bersifat toksik menjadi krom (III) yang kurang toksik (Bae et al., 2005). Penelitian ini bertujuan untuk mengetahui pengaruh konsentrasi awal adsorbat, waktu kontak, dan kecepatan pengadukan pada pengolahan limbah krom dari industri elektroplating. Selain itu, tulisan ini juga mempelajari pemanfaatan bakteri Escherichia coli yang dapat mereduksi krom (VI) yang lebih toksik menjadi krom (III) yang kurang toksik.

\section{BAHAN DAN METODE}

\section{A. Bahan}

Bahan yang digunakan dalam penelitian ini adalah:

1. Kayu kersen (Muntingia calabura L.) yang diambil dari Perumahan Kenari Tanah Baru Bogor

2. Limbah krom dari PT X di Bogor

3. Biakan bakteri Escherichia coli yang merupakan koleksi Laboratorium Pangan dan Mikrobiologi, Politeknik Akademi Kimia Analis, Bogor. 


\section{B. Pengarangan}

Kayu kersen dipotong, kemudian dibuat serpih terlebih dahulu sebelum dicacah. Ukuran serpih kayu yang dibuat arang adalah $0,5 \mathrm{~cm} \mathrm{x}$ $0,5 \mathrm{~cm} \times 0,5 \mathrm{~cm}^{3}$. Cacahan kayu kemudian dicuci dan dikeringkan, kemudian diarangkan pada suhu $500^{\circ} \mathrm{C}$ selama 5 jam dalam tanur tertutup.

\section{Aktivasi}

Arang yang diperoleh ditimbang sebanyak 150 $\mathrm{g}$ dan diaktivasi dengan uap air panas pada suhu $800^{\circ} \mathrm{C}$ dengan variasi waktu 110,90 , dan 70 menit serta variasi tekanan 150 dan $120 \mathrm{mBar}$. Arang aktif yang dihasilkan kemudian dihaluskan dan diayak, sehingga menghasilkan butiran homogen dengan ukuran 100 mesh.

\section{Karakterisasi}

Uji mutu arang dan arang aktif berupa penetapan kadar air, abu, karbon terikat, zat terbang, daya jerap terhadap iod dan metilena biru, serta luas permukaan dilakukan dengan menggunakan metode sesuai Standar Nasional Indonesia 01-3730-1995 (Badan Standardisasi Nasional, 1995). Masing-masing parameter dilakukan sebanyak 4 kali sebagai ulangan.

Untuk mengetahui perubahan struktur yang terjadi selama proses karbonisasi dilakukan analisis gugus fungsi menggunakan Spektrofotometri Infra Merah (IR) tipe Pelkin Elmer 1600. Perangkat Scanning Electron Microscope (SEM) Zeiss tipe EVO-50 dipasangkan dengan perangkat energy dispersive X-ray spectroscopy (EDX). Perangkat ini dipergunakan untuk melihat morfologi dan menentukan kandungan karbon relatif (wt $\%$ ). Untuk mengetahui derajat kristalin $(\mathrm{X})$ digunakan difraksi sinar X (XRD) tipe Shimadzu 7000 dan sumber radiasi tembaga.

\section{E. Uji Adsorpsi}

Sebanyak1 garangaktif kayukersendimasukkan ke dalam tabung erlenmeyer, ditambahkan $30 \mathrm{~mL}$ limbah, kemudian diaduk menggunakan shaker selama 75 menit dengan kecepatan pengadukan $150 \mathrm{rpm}$ dan variasi konsentrasi awal limbah 20-100 mg/L. Setelah diaduk, konsentrasi krom diukur menggunakan Spektrofotometer Serapan Atom (SSA). Percobaan yang sama dilakukan pada konsentrasi optimum dengan variasi waktu kontak 45-105 menit. Kemudian, percobaan yang sama dilakukan pada konsentrasi dan waktu optimum dengan variasi kecepatan pengadukan 100-250 rpm, masing-masing percobaan dilakukan sebanyak 5 kali.

\section{F. Uji Krom Total (SNI 06-6989.17-2004)}

Sebanyak $30 \mathrm{~mL}$ contoh uji yang sudah dikocok sampai homogen dimasukkan ke dalam gelas piala, ditambahkan $5 \mathrm{~mL} \mathrm{HNO}_{3}$ pekat kemudian di panaskan di pemanas listrik sampai larutan contoh uji hampir kering. Setelah dipanaskan, ditambahkan $50 \mathrm{~mL}$ air suling, disaring, dan dimasukkan ke dalam labu ukur $100 \mathrm{~mL}$ dan ditepatkan dengan air suling. Konsentrasi krom diukur menggunakan Spektrofotometer Serapan Atom.

\section{G. Uji Biodegradasi}

Sampel uji biodegradasi diambil dari limbah yang telah diadsorpsi pada konsentrasi awal limbah, waktu kontak, dan kecepatan pengadukan optimum. Kultur murni dari bakteri E. coli yang ditanam dalam media agar miring, diperbanyak dengan menanam dalam nutrient broth selama 48 jam. Selanjutnya kultur disentrifugasi untuk mendapatkan ekstrak bakteri. Sebanyak 1 ose bakteri ditimbang dalam ruang steril dan dilarutkan dalam aquabides yang telah disterilkan untuk memperoleh larutan ekstrak bakteri sebanyak $10 \mathrm{~mL}$. Selanjutnya larutan ekstrak bakteri diambil sebanyak $0,1 \mathrm{~mL}$ dan di tanam dalam media nutrient broth yang mengandung $1 \mathrm{~g}$ arang aktif hasil proses adsorpsi. Perlakuan dibuat dalam erlenmeyer ukuran $250 \mathrm{~mL}$, selanjutnya ditutup dengan kapas dan plastik untuk mencegah kontaminasi dari bakteri atau mikroorganisme yang lain kemudian diinkubasikan selama 14 jam dalam inkubator pada suhu $28^{\circ} \mathrm{C}$. Selanjutnya, sampel disaring menggunakan membran filter, dan hasil saringannya dipipet sebanyak $10 \mathrm{ml}$, kemudian dikomplekskan dengan $2 \mathrm{~mL} 1,5$ difenil karbasid dan dilakukan analisis krom (VI) yang ada dengan menggunakan alat spektrofotometer UV-Visibel pada panjang gelombang $543 \mathrm{~nm}$ (SNI 6989.71:2009). 


\section{HASIL DAN PEMBAHASAN}

\section{A. Uji Mutu Arang dan Arang Aktif}

Penelitian diawali dengan pembuatan arang dari kayu kersen yang kemudian diaktivasi dengan uap air panas menjadi arang aktif dan dilakukan uji mutu berdasarkan SNI 06-3730-1995 (SNI 06-3730, 1995) tentang arang aktif teknis. Data uji mutu arang dan arang aktif dapat dilihat pada Tabel 1.

Kondisi optimum pembuatan arang aktif adalah kondisi perlakuan yang dapat memberikan hasil yang terbaik, berdasarkan atas besarnya hasil kali rendemen dengan daya jerap arang aktif terhadap iodium (Hartoyo et al., 1990; Pari et al., 2009). Dari Tabel 1 dapat dilihat bahwa arang aktif terbaik adalah arang yang diaktivasi pada suhu $800^{\circ} \mathrm{C}$ dan tekanan $120 \mathrm{mBar}$ selama 70 menit. Mutu arang aktif pada variasi tersebut sesuai dengan SNI 06-3730-1995.

\section{Rendemen}

Berdasarkan Tabel 1 dapat dilihat bahwa rendemen arang yang dihasilkan melalui proses karbonisasi adalah 38,63\%. Rendemen yang cukup tinggi ini karena proses karbonisasi dilakukan dengan menggunakan retort listrik secara vakum. Pengarangan yang tidak dilakukan secara vakum akan dipengaruhi oleh adanya udara, sehingga kadar rendemen arang yang dihasilkan akan rendah. Jumlah udara yang cukup besar menyebabkan bahan akan mengalami oksidasi secara berlebihan dan akan menyebabkan terbentuknya abu yang cukup banyak dibandingkan arang.

Semakin lama waktu aktivasi akan mengakibatkan rendemen arang aktif semakin rendah (Pari et al., 2008). Rendemen arang aktif tergantung pada bahan baku dan perlakuan aktivasi, yaitu suhu, waktu, dan bahan pengaktif. Dari Tabel 1 dapat dilihat, bahwa rendemen

Tabel 1. Uji mutu arang dan arang aktif

Table 1. Charcoal and activated charcoal quality test

\begin{tabular}{|c|c|c|c|c|c|c|c|c|}
\hline \multirow{3}{*}{$\begin{array}{l}\text { Parameter } \\
\text { (Parameters) }\end{array}$} & \multirow{3}{*}{$\begin{array}{l}\text { Arang } \\
\text { (Charcoal) }\end{array}$} & \multicolumn{6}{|c|}{ Arang Aktif (Activated Charcoal) } & \multirow{3}{*}{$\begin{array}{c}\text { SNI } \\
06-3730-1995\end{array}$} \\
\hline & & \multicolumn{6}{|c|}{$\begin{array}{l}\text { Variasi Waktu (Menit) / Tekanan (MBar) } \\
\text { Time (Minutes) / Pressure (Mbar) Variation }\end{array}$} & \\
\hline & & $70 / 120$ & $90 / 120$ & $110 / 120$ & $70 / 150$ & $90 / 150$ & $110 / 150$ & \\
\hline \multicolumn{9}{|c|}{ Rendemen (Yield, \%) } \\
\hline Rerata (Average) & 38,63 & 50,66 & 36,00 & 17,33 & 42,00 & 8,66 & 6,66 & \\
\hline $\mathrm{SD}$ & 0,02 & 0,01 & 0,01 & 0,01 & 0,01 & 0,01 & 0,01 & \\
\hline \multicolumn{9}{|c|}{ Kadar air (Moisture content, \%) } \\
\hline Rerata (Average) & 1,11 & 0,86 & 1,21 & 1,93 & 1,20 & 4,24 & 5,54 & $<15$ \\
\hline $\mathrm{SD}$ & 0,01 & 0,01 & 0,02 & 0,01 & 0,02 & 0,02 & 0,01 & \\
\hline \multicolumn{9}{|c|}{ Kadar zat terbang (Volatile subtance content, \%) } \\
\hline Rerata (Average) & 22,44 & 9,76 & 9,17 & 9,33 & 11,30 & 13,39 & 13,16 & $<25$ \\
\hline SD & 0,01 & 0,01 & 0,01 & 0,02 & 0,01 & 0,02 & 0,02 & \\
\hline \multicolumn{9}{|c|}{ Kadar abu (Ash content, \%) } \\
\hline Rerata (Average) & 4,07 & 6,44 & 7,53 & 11,42 & 8,22 & 8,27 & 12,59 & $<10$ \\
\hline $\mathrm{SD}$ & 0,01 & 0,01 & 0,01 & 0,02 & 0.02 & 0,01 & 0,02 & \\
\hline \multicolumn{9}{|c|}{ Kadar karbon terikat (Bounded carbon content, \%) } \\
\hline Rerata (Average) & 73,49 & 83,80 & 83,30 & 79,25 & 80,48 & 78,34 & 74,25 & $>65$ \\
\hline SD & 0,01 & 0,01 & 0,02 & 0,01 & 0,02 & 0,01 & 0,01 & \\
\hline \multicolumn{9}{|c|}{ Daya serap iod (Iod adsorption, mg/g) } \\
\hline Rerata (Average) & 216,1 & 912,1 & 908,3 & 1119,9 & 1014,5 & 955,8 & 1012,9 & $>750$ \\
\hline SD & 0,01 & 0,01 & 0,01 & 0,01 & 0,02 & 0,02 & 0,02 & \\
\hline \multicolumn{9}{|c|}{ Daya serap biru metilena (Metbylene blue adsorption, mg/g) } \\
\hline Rerata (Average) & 93,96 & 218,10 & 220,80 & 245,90 & 227,20 & 228,90 & 241,90 & $>120$ \\
\hline SD & 0,01 & 0,01 & 0,01 & 0,01 & 0,01 & 0,01 & 0,01 & \\
\hline \multicolumn{9}{|c|}{ Luas permukaan (Surface area, $\mathrm{m}^{2} / \mathrm{g}$ ) } \\
\hline Rerata (Average) & 348,41 & 808,72 & 818,71 & 911,78 & 844,29 & 848,76 & 896,96 & \\
\hline SD & 0,02 & 0,02 & 0,02 & 0,02 & 0,02 & 0,03 & 0,02 & \\
\hline \multicolumn{9}{|c|}{ Kondisi optimum (Optimum conditions) } \\
\hline Rerata (Average) & 8347,94 & 16206,97 & 32699,16 & 19410,58 & $42,613,97$ & 8282,01 & 6748,43 & \\
\hline
\end{tabular}

Keterangan (Remarks): SD = Standar deviasi (Standard deviation) 
Tabel 2. Bilangan gelombang serapan inframerah Table 2. Infrared adsorption wave number

\begin{tabular}{ll}
\hline \multicolumn{1}{c}{ Struktur (Structures) } & Bilangan gelombang $\left(\right.$ Wave number $\left.\mathrm{cm}^{-1}\right)$ \\
\hline Kayu kersen (Muntingia calabura wood) & $3027-2016-1541-1178-867$ \\
Arang (Charcoal) & $3027-2666-1698-568-1485-1437-1394-1290-1187-815-461$ \\
Arang aktif (Activated charcoal) & $3684-3664-1787-1696-1531-1484-1436-1393-1289-1178-1141-1090-686-418-403$ \\
\hline
\end{tabular}

yang dihasilkan berkisar antara 6,66-50,66\%. Berkurangnya rendemen disebabkan oleh senyawa karbon yang terbentuk dari hasil penguraian selulosa dan lignin mengalami reaksi pemurnian dengan uap air yang bertujuan untuk menghilangkan senyawa non karbon yang melekat pada permukaan arang. Namun demikian karena reaksi yang terjadi secara radikal maka atom $\mathrm{C}$ yang terbentuk akan bereaksi kembali dengan atom $\mathrm{O}$ dan $\mathrm{H}$ membentuk $\mathrm{CO}, \mathrm{CO}_{2}, \mathrm{CH}_{4}$, sehingga rendemen arang aktif yang dihasilkan akan lebih rendah. Semakin lama waktu aktivasi pada tekanan yang sama, maka kadar rendemennya akan semakin berkurang.

\section{Kadar air}

Salah satu karakteristik yang sangat penting pada arang aktif adalah kadar air, karena mampu mempengaruhi daya jerap terhadap cairan dan gas. Hendra (2007) melaporkan, bahwa besarnya kadar air dipengaruhi oleh sifat arang aktif yang higroskopis, sehingga uap air dapat terperangkap dalam kisi-kisi heksagonal arang aktif, terutama pada saat pendinginan. Berdasarkan Tabel 1 dapat dilihat bahwa kadar air yang terdapat dalam arang yang dihasilkan adalah 1,11\%. Kadar air yang rendah disebabkan adanya penguapan air pada saat proses karbonisasi. Kadar air arang aktif adalah antara 0,86-5,54\%, sesuai dengan SNI 06-37301995, yaitu kurang dari 15\%. Rendahnya kadar air menunjukkan bahwa kandungan air bebas dan air terikat telah menguap selama proses karbonisasi. Semakin tinggi tekanan dan semakin lama waktu aktivasi, maka kadar air semakin rendah.

\section{Kadar zat terbang}

Kadar zat terbang merupakan parameter untuk mengukur banyaknya zat yang menguap pada saat proses pemanasan. Parameter tersebut dapat digunakan untuk mengukur tingkat kemampuan adsorpsi arang aktif, semakin tinggi zat terbang, maka daya adsorpsinya terhadap larutan dan gas akan semakin rendah. Rumidatul (2006) melaporkan, bahwa kadar zat terbang atau mudah menguap menunjukkan banyaknya zat mudah menguap yang hilang pada pemanasan $950^{\circ} \mathrm{C}$ berupa senyawaan karbon, sulfur, dan nitrogen yang dapat menutupi pori-pori arang aktif. Kadar zat terbang merupakan banyaknya zat yang mudah menguap karena adanya dekomposisi senyawa-senyawa yang masih terdapat di dalam arang selain dari air. Dari Tabel 1 dapat dilihat, bahwa kadar zat terbang arang aktif berkisar antara 9,17-13,39\% sesuai dengan SNI 06-37301995 yaitu kurang dari 25\%.

Analisis secara spektrofotometri inframerah bertujuan untuk mengetahui perubahan gugus fungsi sebagai akibat dari proses pengarangan menjadi arang aktif yang hasilnya tercantum pada Tabel 2. Pola spektrum serapan inframerah kayu, arang dan arang aktif dapat dilihat pada Gambar 1, 2, dan 3 .

Analisis menggunakan spektrophotometer inframerah pada kayu kersen memperlihatkan adanya alkena $\left(\mathrm{H}_{2} \mathrm{C}=\mathrm{CH}_{2}\right)$ pada bilangan gelombang $3027 \mathrm{~cm}^{-1}$ dan cincin aromatik $(\mathrm{C}=\mathrm{C})$ pada bilangan gelombang $1541 \mathrm{~cm}^{-1}$ dan cincin aromatik (C-H) pada $867 \mathrm{~cm}^{-1}$. Selain itu, tercatat alkohol dan asam karboksilat (C-O) yang mudah menguap pada bilangan gelombang $867 \mathrm{~cm}^{-1}$ (Skoog et al., 1998).

Analisis pada arang memperlihatkan adanya alkena $\left(\mathrm{H}_{2} \mathrm{C}=\mathrm{CH}_{2}\right)$ dan cincin aromatik $(\mathrm{C}-\mathrm{H})$ pada bilangan gelombang $3027 \mathrm{~cm}^{-1}$ dan $815 \mathrm{~cm}^{-1}$. Selain itu terdapat ikatan hidrogen dan oksigen pada asam karboksilat (H-O) pada bilangan gelombang $2666 \mathrm{~cm}^{-1}$, ikatan karbon pada asam karboksilat (C-0) pada $1698 \mathrm{~cm}^{-1}$, ikatan karbon dan hidrogen pada alkana $(\mathrm{C}-\mathrm{H})$ pada $1437 \mathrm{~cm}^{-1}$ dan $1394 \mathrm{~cm}^{-1}$, serta ikatan karbon dan oksigen pada alkohol dan asam karboksilat (C-O) pada $1290 \mathrm{~cm}^{-1}$ dan $1187 \mathrm{~cm}^{-1}$ (Skoog et al., 1998).

Analisis pada arang aktif memperlihatkan adanya asam karboksilat $(\mathrm{C}=\mathrm{O})$ pada bilangan gelombang $1696 \mathrm{~cm}^{-1}$, juga asam karboksilat dan 


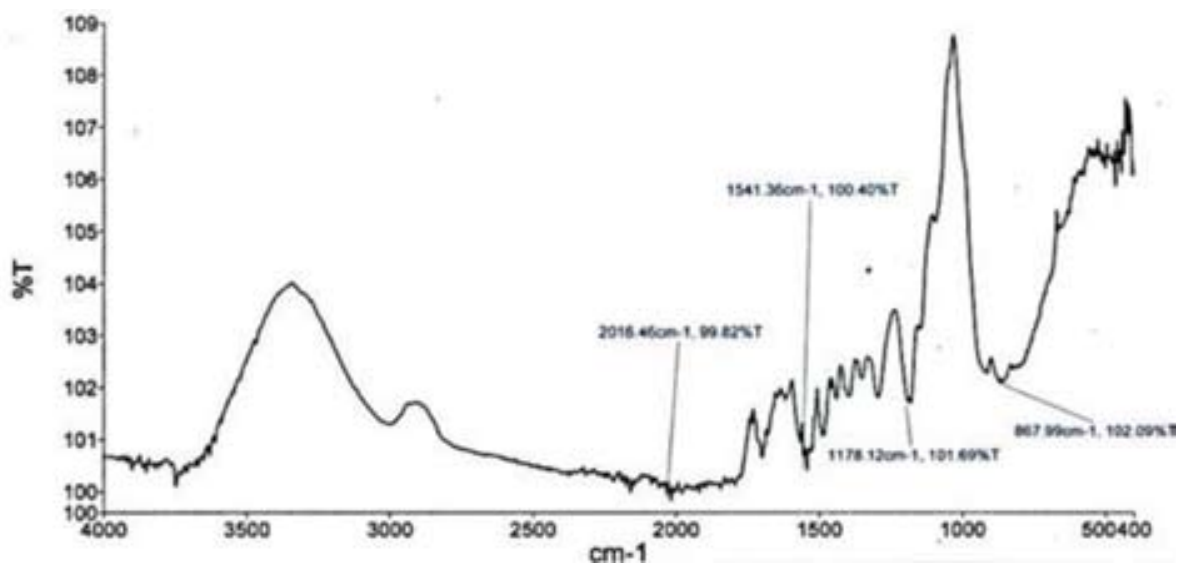

Gambar 1. Spektrum serapan inframerah kayu kersen Figure 1. Mutingia calabura L. infrared adsorption spectrum

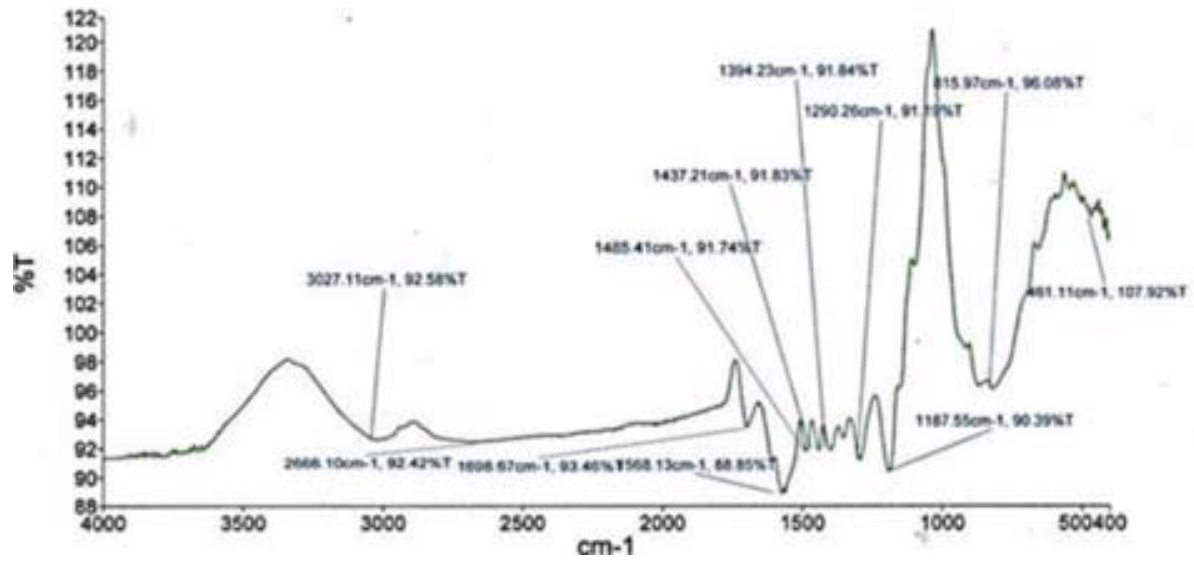

Gambar 2. Spektrum serapan inframerah arang Figure 2. Charcoal infrared adsorption spectrum

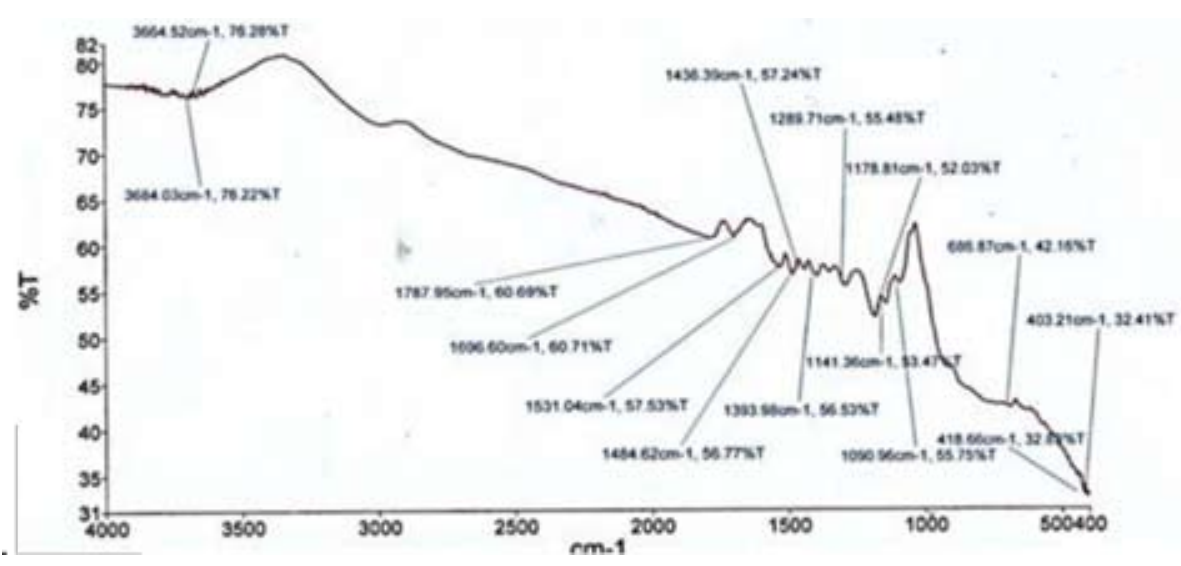

Gambar 3. Spektrum serapan inframerah arang aktif Figure 3. Charcoal activated infrared adsorption spectrum

alkohol (C-O) pada $1289 \mathrm{~cm}^{-1}, 1178 \mathrm{~cm}^{-1}, 1141$ $\mathrm{cm}^{-1}$ dan $1090 \mathrm{~cm}^{-1}$. Selain itu, terdapat juga cincin aromatik $(\mathrm{C}=\mathrm{C})$ pada bilangan gelombang
$1531 \mathrm{~cm}^{-1}$ dan cincin aromatik (C-H) dan alkena pada $686 \mathrm{~cm}^{-1}$, serta alkana $(\mathrm{C}-\mathrm{H})$ pada $1436 \mathrm{~cm}^{-1}$ dan $1393 \mathrm{~cm}^{-1}$ (Skoog et al., 1998). 


\section{Kadar Abu}

Kadar abu merupakan komponen anorganik bahan yang tertinggal pada pemanasan 700 ${ }^{\circ} \mathrm{C}$. Menurut Rumidatul (2006), kadar abu menunjukkan jumlah oksida-oksida logam yang tersisa pada pemanasan tinggi. Abu yang terbentuk berasal dari mineral-mineral yang terikat kuat pada arang, seperti kalsium, kalium dan magnesium. Dari Tabel 1 dapat dilihat bahwa kadar abu yang diperoleh berkisar antara 6,44-12,59\%, sedangkan SNI 06-3730-1995 mensyaratkan kadar abu tidak lebih dari 10\%. Kadar abu yang diinginkan adalah serendah mungkin, sehingga adsorpsi dapat berjalan dengan baik.

Proses karbonisasi pada arang menggunakan suhu $500^{\circ} \mathrm{C}$ dan pada proses aktivasi arang aktif menggunakan suhu $800^{\circ} \mathrm{C}$. Perbedaan suhu yang digunakan menyebabkan terbentuknya pengotor berupa abu yang merupakan hasil degradasi senyawa anorganik atau mineral oleh suhu tinggi. Pada arang abu yang terbentuk lebih sedikit daripada arang aktif, karena suhu yang digunakan pada saat karbonisasi lebih rendah, sehingga senyawa mineral pada arang masih belum terdegradasi sempurna.

Pari (2004) melaporkan, bahwa abu yang terbentuk berasal dari mineral-mineral seperti kalsium, kalium, natrium, dan magnesium di dalam bahan yang menyebar dalam kisi-kisi arang aktif. Adanya kalium selain karbon pada batang kersen, arang, dan arang aktif secara kuantitatif menggunakan Energy Dispersive X-Ray (EDX) dapat dilihat pada Tabel 3.

Kadar abu berasal dari mineral seperti $\mathrm{K}, \mathrm{Ca}$, $\mathrm{Na}$, dan $\mathrm{Mg}$, hanya yang terpenting di dalam arang aktif adalah unsur C-nya. Dari Tabel 3 dapat dilihat bahwa kandungan atom karbon yang terdapat pada arang aktif menghasilkan persentase paling tinggi. Proses aktivasi mengakibatkan hilangnya unsur pengotor lainnya pada karbon, sehingga tingginya unsur karbon yang berada pada karbon aktif teraktivasi dapat meningkatkan daya adsorpsinya. Grafik kandungan unsur kayu kersen, arang, dan arang aktif hasil pengujian EDX dapat dilihat pada Gambar 4, 5, dan 6.

\section{Kadar Karbon Terikat}

Karbon dalam arang adalah zat yang terdapat pada fraksi padat hasil pirolisis selain abu (zat organik) dan zat lain yang masih terdapat pada pori-pori arang. Definisi kadar karbon terikat hanya berupa pendekatan (Rumidatul, 2006). Pari (2004) melaporkan, bahwa besar kecilnya kadar karbon terikat dipengaruhi oleh kadar abu dan kadar zat terbang. Selain itu juga dipengaruhi oleh kandungan selulosa dan lignin yang dapat dikonversi menjadi atom karbon juga turut berpengaruh. Berdasarkan Tabel 1 dapat dilihat, bahwa kadar karbon terikat arang aktif berkisar antara 74,25-83,80\% sesuai dengan SNI 06-3730 yaitu lebih besar dari 65\%. Kadar karbon terikat berbanding terbalik dengan kadar abu dan kadar zat terbang.

\section{Daya Jerap terhadap Iodium}

Tujuan dari penetapan daya jerap arang aktif terhadap iodium adalah untuk mengetahui kemampuan arang aktif dalam menyerap larutan berwarna atau kotoran. Besarnya daya jerap arang aktif terhadap iodium memperlihatkan besarnya diameter pori arang aktif yang dapat dimasuki oleh molekul yang ukurannya tidak lebih besar dari 10 Å dan banyaknya struktur mikropori yang terbentuk (Prastiwi, 2013). Dari Tabel 1 dapat dilihat, bahwa daya jerap arang aktif terhadap iodium berkisar antara 908,3-1119,9 mg/g, sesuai dengan SNI 06-3730-1995, yaitu lebih besar dari $750 \mathrm{mg} / \mathrm{g}$. Daya jerap iodium yang diinginkan adalah daya jerap iodium yang tinggi, semakin tinggi daya jerap iodium, semakin baik kualitas arang aktif tersebut.

Tabel 3. Kandungan unsur kayu kersen, arang, dan arang aktif Table 3. Element content of Mutingia calabura L., charcoal, and activated charcoal

\begin{tabular}{lccc}
\hline \multicolumn{1}{c}{$\begin{array}{c}\text { Struktur } \\
\text { (Structures) }\end{array}$} & \multicolumn{3}{c}{ Unsur (Element, \%) } \\
\cline { 2 - 4 } & $\mathrm{C}$ & $\mathrm{O}$ & $\mathrm{K}$ \\
\hline Kayu (Wood) & 59,65 & 39,90 & 0,44 \\
Arang (Charcoal) & 80,79 & 18,39 & 0,82 \\
Arang Aktif (Activated charcoal) & 94,34 & 3,26 & 2,40 \\
\hline
\end{tabular}




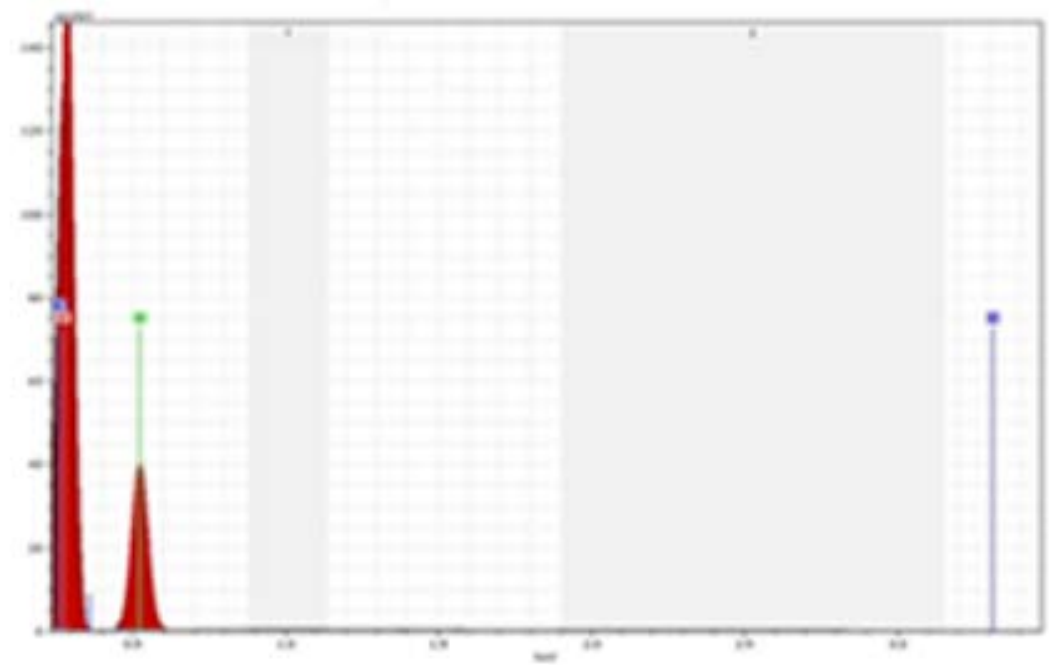

Gambar 4. Hasil EDX kayu kersen Figure 4. EDX result of Mutingia calabura $L$.

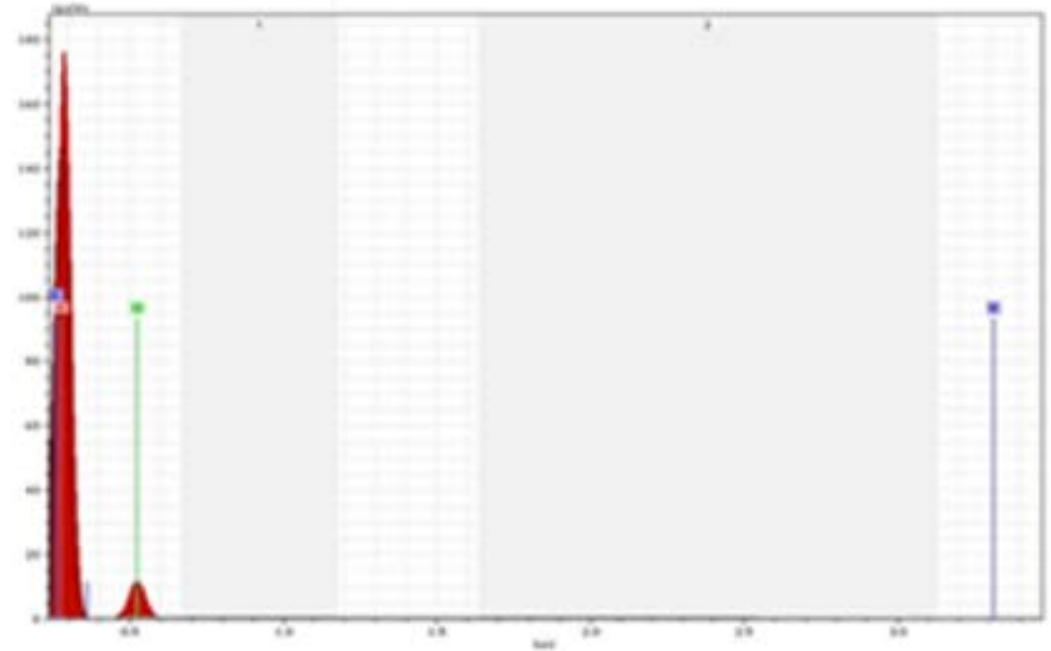

Gambar 5. Hasil EDX arang

Figure 5. EDX result of charcoal

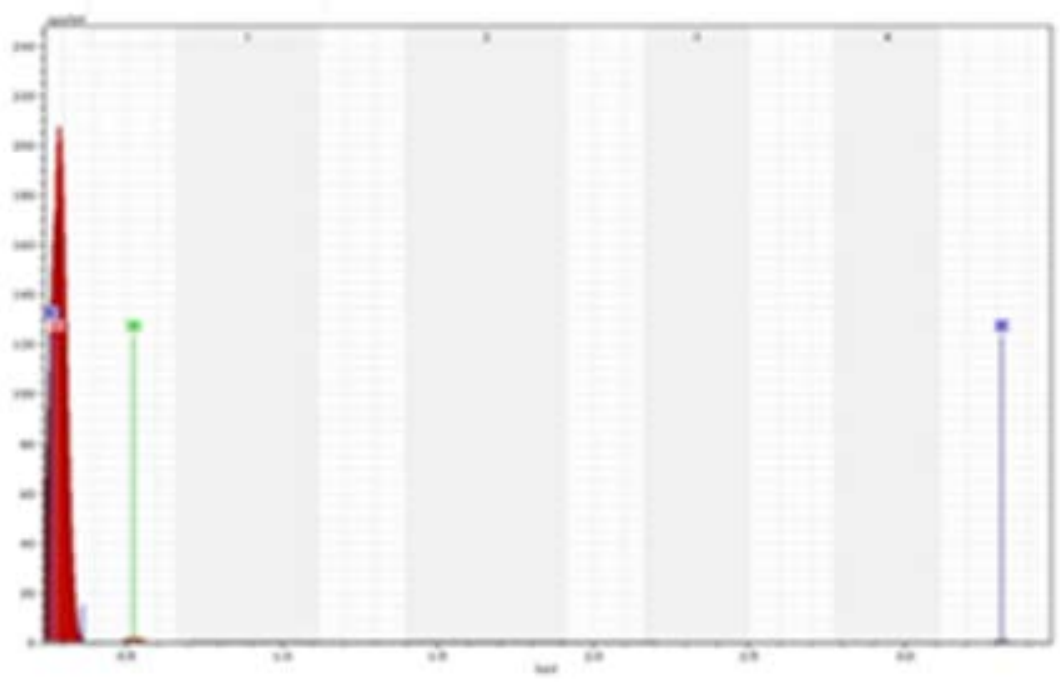

Gambar 6. Hasil EDX arang aktif

Figure 6. EDX result of activated charcoal 
Tabel 4. Data derajat kristalin dan daya jerap terhadap iod

Table 4. Data of crystalline degrees and iod adsorption

\begin{tabular}{lcc}
\hline \multicolumn{1}{c}{$\begin{array}{c}\text { Struktur } \\
\text { (Structure })\end{array}$} & $\begin{array}{c}\text { Derajat kristalin } \\
\text { (Crystallinity degree, \%) }\end{array}$ & $\begin{array}{c}\text { Daya serap iod } \\
\text { (Iod adsorption, mg/g) }\end{array}$ \\
\hline Kayu kersen (Mutingia calabura L.) & 31,94 & - \\
Arang (Charcoal) & 29,84 & 216,1 \\
Arang Aktif (Activated charcoal) & 20,61 & 912,1 \\
\hline
\end{tabular}

Tabel 5. Hasil pengujian difraktogram

Table 5. XRD Difractogram test results

\begin{tabular}{lcccccccc}
\hline $\begin{array}{c}\text { Struktur } \\
\text { (Structures) }\end{array}$ & $\mathrm{X}(\%)$ & $\Theta$ & $\mathrm{d}(\mathrm{nm})$ & $\theta$ & $\mathrm{d}(\mathrm{nm})$ & $\mathrm{Lc}(\mathrm{nm})$ & $\mathrm{N}$ & $\mathrm{La}(\mathrm{nm})$ \\
\hline Kayu kersen (Muntingia calabura L.) & 31,94 & 21,13 & 0,42 & 44,51 & 0,20 & 5,24 & 12,47 & - \\
Arang (Charcoal) & 29,84 & 22,07 & 0,40 & 43,49 & 0,21 & 1,46 & 3,63 & - \\
Arang aktif (Activated Carcoal) & 20,61 & 23,48 & 0,38 & 43,31 & 0,21 & 1,37 & 3,61 & 8,22 \\
\hline
\end{tabular}

Analisis dengan difraksi sinar X (XRD) bertujuan untuk mengetahui struktur kristalit kayu kersen, arang, dan arang aktif. Dengan analisis ini dapat diketahui perubahan bentuk kristalit sebagai akibat karbonisasi dan aktivasi. Besar kecilnya daya jerap iod dipengaruhi oleh derajat kristalin seperti terlihat pada Tabel 4.

Dari Tabel 4 dapat dilihat, bahwa derajat kristalin arang aktif lebih kecil dibandingkan dengan arang dan kayu kersen. Hal ini disebabkan adanya pemanasan pada waktu pembuatan arang dan arang aktif, sehingga terjadi penyusutan struktur kristalin yang semakin teratur yang mengakibatkan celah di antara kristalin semakin lebar dan pori yang terbentuk bertambah besar. Makin kecil derajat kristalin, semakin besar daya jerap terhadap Iod. Difraktogram XRD dari kayu kersen, arang dan arang aktif dapat dilihat pada Tabel 5, Gambar 8, 9, dan 10.

Tabel 5, Gambar 8, 9, dan 10 menunjukkan, bahwa tinggi lapisan (Lc) antar susunan kristalin arang aktif lebih kecil dibandingkan arang dan kayu kersen. Hal ini menggambarkan adanya penyusutan ikatan antar karbon, sehingga jarak (d) antar lapisan aromatik bertambah pendek dan jumlah $(\mathrm{N})$ lapisan berkurang, serta lebar

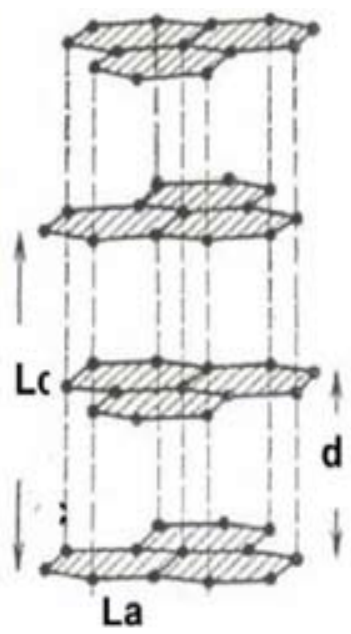

Gambar 7. Skema tinggi lapisan (Lc), jumlah lapisan (N), jarak antar lapisan (d), dan lebar lapisan (La) aromatik struktur kristalit arang

Figure 7. Height scheme (Lc), number (N), distance between layers (d) and width (La) of aromatic layers of charcoal crystalyte structure

Sumber (Source) : Schukin et al. (2002) 


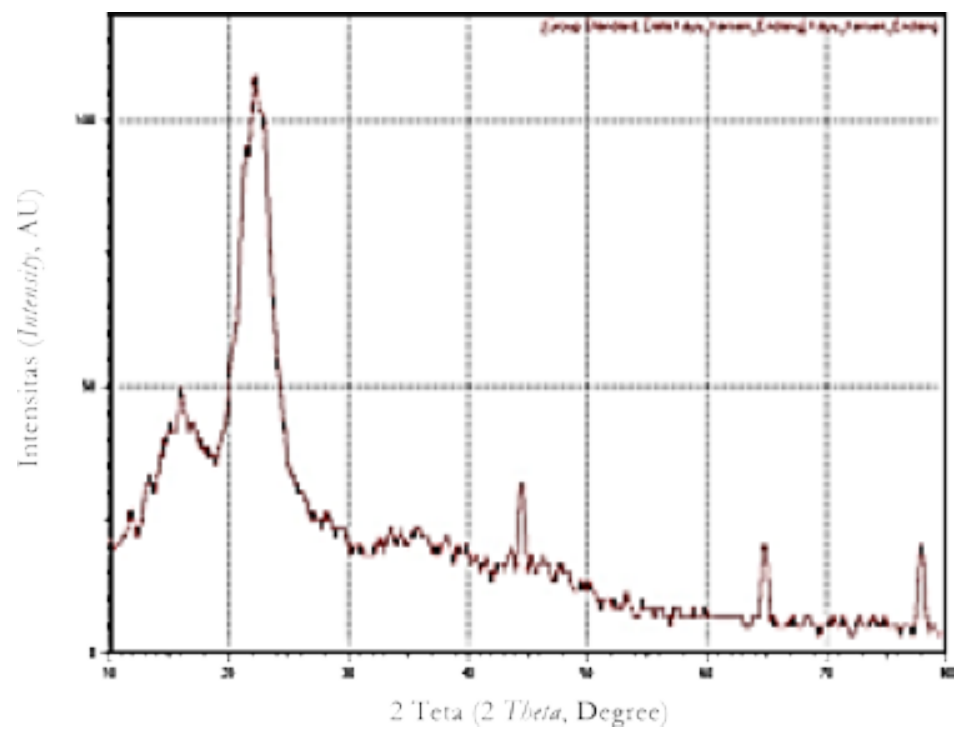

Gambar 8. Difraktogram XRD kayu kersen

Figure 8. XRD diffractogram of Mutingia calabura $L$.

(La) lapisan aromatiknya melebar. Skema tinggi lapisan (Lc), jarak antar lapisan (d), jumlah lapisan $(\mathrm{N})$, dan lebar lapisan dapat dilihat pada Gambar 7.

Menurut Pari (2004) peningkatan suhu mengakibatkan terjadinya pergeseran antar lapisan kristalin dan merubah struktur bahan baku, sehingga terbentuk pola struktur baru yang berbeda dari asalnya.
7. Daya jerap terhadap biru metilena dan luas permukaan

Daya jerap arang aktif terhadap biru metilena yang diinginkan adalah daya jerap yang tinggi. Tingginya nilai daya jerap terhadap biru metilena memperlihatkan, bahwa senyawa hidrokarbon yang terdapat pada permukaan arang yang diaktivasi telah banyak menjadi aktif dan ikatan antara hidrogen dan karbon telah banyak yang

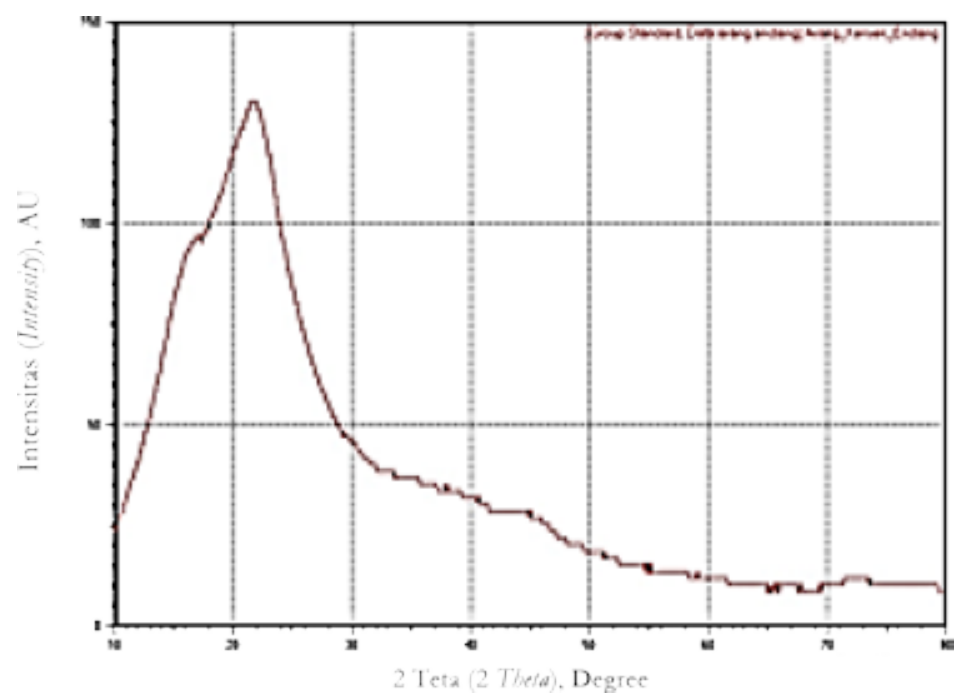

Gambar 9. Difraktogram XRD arang Figure 9. XRD Diffractogram of Charcoa 


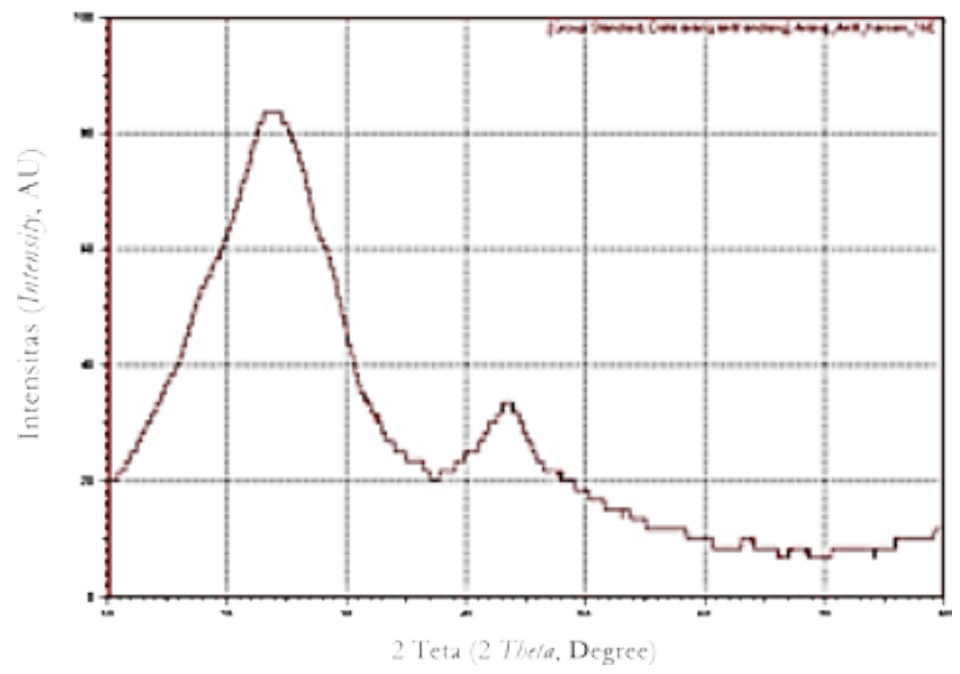

Gambar 10. Difraktogram XRD arang aktif Figure 10. XRD diffractogram of activated charcoal

terlepas pula, sehingga luas permukaannyapun semakin luas. Dari Tabel 1 dapat dilihat, bahwa daya jerap arang aktif terhadap biru metilena berkisar antara 218,1-245,9 mg/g. Menurut SNI 06-3730-1995, daya jerap arang aktif terhadap metilena biru adalah lebih besar dari $120 \mathrm{mg} / \mathrm{g}$. Dari Tabel 1 dapat dilihat bahwa luas permukaannya antara 808,72 - 911,78 $\mathrm{m}^{2} / \mathrm{g}$, dan tidak ada syarat luas permukaan pada SNI 06-3730-1995. Daya jerap arang aktif terhadap metilena biru adalah lebih besar dari $120 \mathrm{mg} / \mathrm{g}$.

Dari Tabel 1 dapat dilihat bahwa luas permukaan antara $808,72-911,78 \mathrm{~m}^{2} / \mathrm{g}$, dan tidak ada syarat luas permukaan pada SNI 063730-1995. Semakin besar daya jerap terhadap biru metilena, maka semakin besar pula luas permukaannya. Semakin lama waktu aktivasi pada tekanan yang sama, maka semakin besar daya jerap terhadap metilena biru dan semakin besar pula luas permukaannya. Pori-pori yang terbentuk diamati menggunakan Scanning Electron Microscopy (SEM) dan diameter porinya dapat dilihat pada Tabel 6 .
Morfologi batang kersen, arang, dan arang aktif dapat dilihat pada Gambar 11, 12, dan 13.

Hasil gambar SEM menunjukkan bahwa bahan baku berupa kayu kersen tidak terlihat adanya pori (Gambar 11). Setelah kayu kersen diarangkan, maka mulai terbentuk pori dengan ukuran diameter pori 2-8 $\mu \mathrm{m}$ (Gambar 12). Setelah menjadi arang aktif, jumlah pori semakin meningkat dan ukuran diameter pori juga semakin besar, yaitu antara 4-14 $\mu \mathrm{m}$, akibat proses aktivasi (Gambar 13). Menurut Beukens et al. (1985) di dalam Rumidatul (2006), ukuran pori tersebut termasuk ke dalam struktur makropori, karena diameter porinya lebih dari 0,025 $\mu \mathrm{m}$. Pada arang masih terdapat struktur pori yang masih kecil, sehingga kemampuan dalam menyerap larutan dan gas masih rendah. Pada arang aktif telah terbentuk struktur pori yang lebih luas dan menyebar di seluruh permukaan. Semakin banyak struktur pori pada permukaan arang aktif, maka kemampuan dalam menyerap cairan dan gas akan semakin tinggi. Proses karbonisasi dan aktivasi mempengaruhi struktur pori-pori suatu bahan.

Tabel 6. Diameter permukaan pori

Table 6. Pore surface diameter

\begin{tabular}{lc}
\hline \multicolumn{1}{c}{ Struktur (Structures) } & Diameter pori (Pore diameter, $\mu \mathrm{m})$ \\
\hline Kayu kersen (Muntingia calabura L.) & - \\
Arang (Charcoal) & $2-8$ \\
Arang Aktif (Activated charcoal) & $4-14$ \\
\hline
\end{tabular}




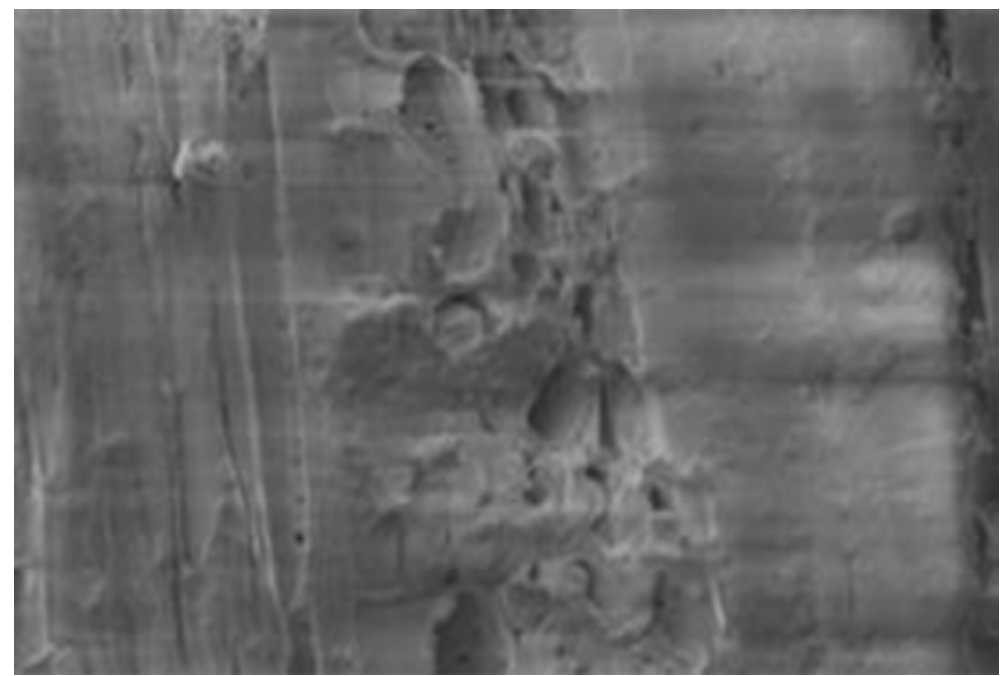

Gambar 11. Morfologi permukaan kayu kersen 500x Figure 11. Morphology of Muntingia calabura L. surfaces 500x

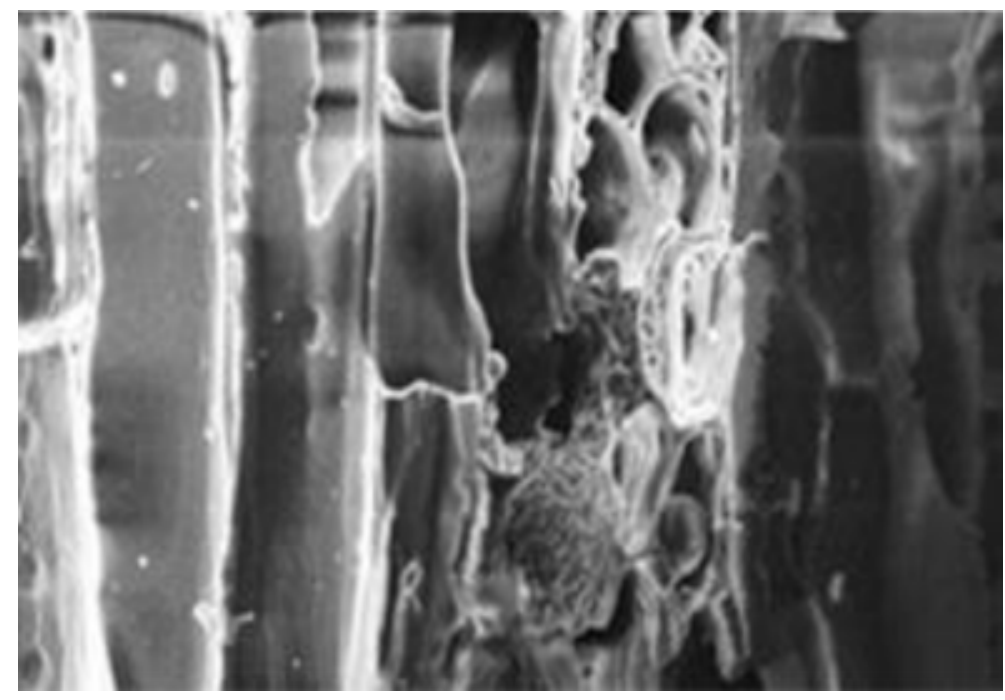

Gambar 12. Morfologi permukaan arang 1000x

Figure 12. Morphology of charcoal surfaces 1000x

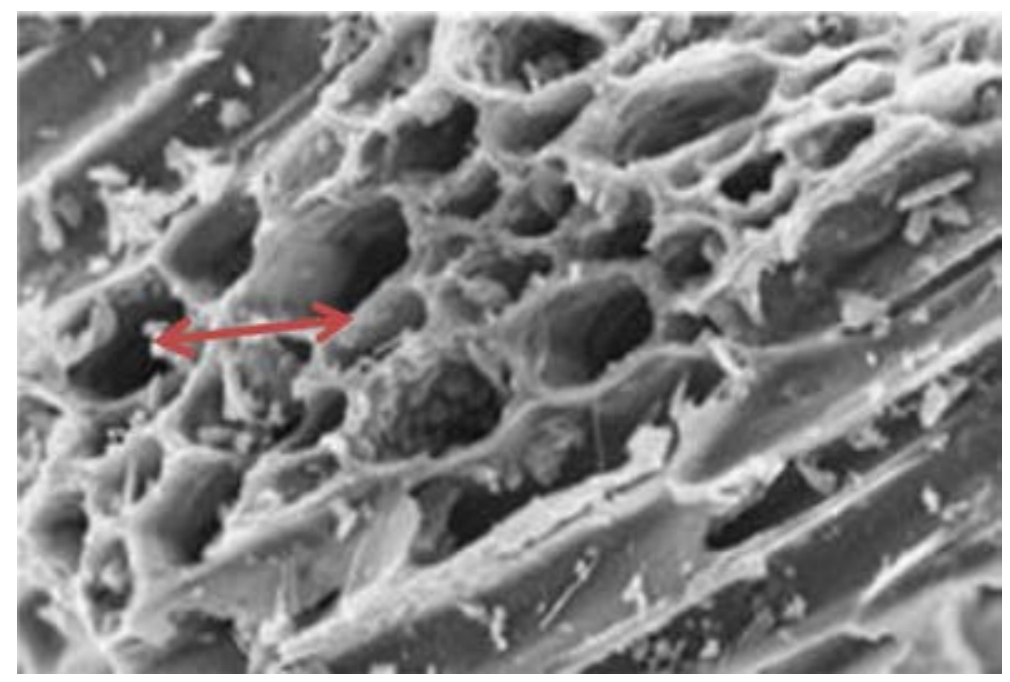

Gambar 13. Morfologi permukaan arang aktif 1000x Figure 13. Morphology of activated charcoal surfaces 1000x 
Tabel 7. Data proses adsorpsi dengan variasi konsentrasi awal Table 7. Adsorption process data with initial concentration variation

\begin{tabular}{|c|c|c|c|}
\hline \multirow{3}{*}{$\begin{array}{l}\text { Variasi Konsentrasi } \\
\text { (Concentration Variation, } \mathrm{mg} / \mathrm{L} \text { ) }\end{array}$} & \multicolumn{2}{|c|}{$\begin{array}{c}\text { Konsentrasi Hasil Pengukuran } \\
\text { (Concentration of measurement results, mg/L) }\end{array}$} & \multirow{3}{*}{$\begin{array}{l}\text { Efektivitas } \\
\text { (Effectivity, \%) }\end{array}$} \\
\hline & Awal (Before) & Akhir (After) & \\
\hline & Rerata (Average, SD) & Rerata (Average, SD) & \\
\hline 20 & $3,1224(0,0003)$ & $2,9396(0,0004)$ & 5,86 \\
\hline 30 & $9,5643(0,0067)$ & $8,7817(0,0103)$ & 8,18 \\
\hline 40 & $15,5949(0,0013)$ & $13,9856(0,0046)$ & 10,32 \\
\hline 50 & $22,4152(0,0116)$ & $18,4227(0,0085)$ & 17,81 \\
\hline 60 & $26,2064(0,0203)$ & $17,1651(0,0057)$ & 34,50 \\
\hline 65 & $28,1858(0,0036)$ & $10,4782(0,0054)$ & 62,82 \\
\hline 70 & $31,8432(0,0004)$ & $4,2430(0,0010)$ & 86,68 \\
\hline 75 & $33,4465(0,0013)$ & $15,8358(0,0015)$ & 52,65 \\
\hline 80 & $34,9148(0,0088)$ & $26,1748(0,0029)$ & 25,03 \\
\hline 90 & $38,9099(0,0001)$ & $34,5715(0,0007)$ & 11,15 \\
\hline 100 & $42,1434(0,0011)$ & $38,7679(0,0041)$ & 8,01 \\
\hline
\end{tabular}

Keterangan (Remarks) : (SD) = Standar Deviasi (Standart Deviation); Kosentrasi awal adalah konsentrasi sebelum adsorpsi (Initial concentration mean Concentration before adsorption); Konsentrasi akhir adalah konsentrasi setelah adsorpsi (Last concentration mean Concentration after adsorption).

Pori-pori terbentuk dari penguapan zat terbang serta terdegradasinya senyawa organik oleh panas. Pori-pori yang terbentuk memiliki gaya Van der Walls, yaitu gaya yang dapat menarik molekul, sehingga terjadi peristiwa adsorpsi.

\section{B. Uji Adsorpsi}

1. Pengaruh konsentrasi awal adsorbat

Konsentrasi awal adsorbat merupakan salah satu faktor yang mempengaruhi efektivitas adsorpsi, karena berkaitan dengan transfer massa yang terjadi pada permukaan adsorben. Variasi konsentrasi awal adsorbat dilakukan antara 20-100 mg/L dengan waktu kontak 75 menit dan kecepatan pengadukan $150 \mathrm{rpm}$. Data hasil pengukurannya dapat dilihat pada Tabel 7.

Dari Tabel 7 dapat dilihat bahwa efektivitas maksimum didapat sebesar 86,68\% pada konsentrasi awal $70 \mathrm{mg} / \mathrm{L}$. Pengaruh konsentrasi awal limbah krom terhadap besarnya efektifitas pada adsorpsi batang kersen dapat dilihat pada Gambar 14.

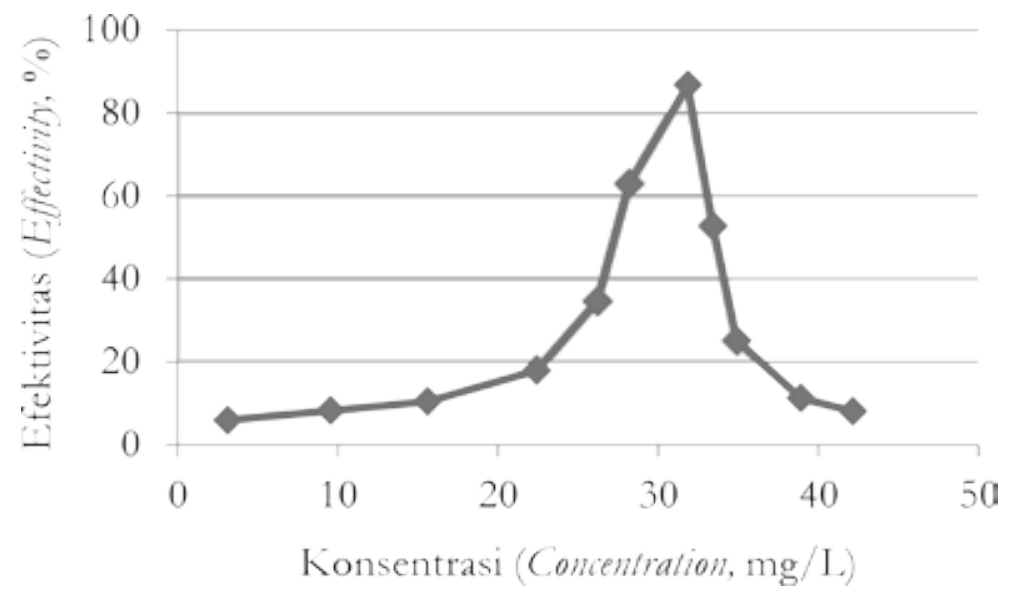

Gambar 14. Grafik kondisi optimum efektivitas daya jerap dengan konsentrasi awal limbah Figure 14. Graph of the optimum condition of adsorption effectivity with initial waste concentration 
Tabel 8. Data pada proses adsorpsi dengan variasi waktu kontak Figure 8. Adsorption process data with contact time variation

\begin{tabular}{|c|c|c|c|}
\hline \multirow{3}{*}{$\begin{array}{l}\text { Waktu Kontak } \\
\text { (Contact time, minute) }\end{array}$} & \multicolumn{2}{|c|}{$\begin{array}{c}\text { Konsentrasi Hasil Pengukuran } \\
\text { (Concentration of measurement results, } \mathrm{mg} / \mathrm{L} \text { ) }\end{array}$} & \multirow{3}{*}{$\begin{array}{l}\text { Efektivitas } \\
\text { (Effectivity, \%) }\end{array}$} \\
\hline & \multirow{2}{*}{ Awal (Initial, SD) } & Akhir (Final) & \\
\hline & & Rerata (Average, SD) & \\
\hline 45 & \multirow{9}{*}{$31,8432(0,0004)$} & $26,5852(0,0013)$ & 16,51 \\
\hline 60 & & $24,3884(0,0004)$ & 23,41 \\
\hline 65 & & $18,9376(0,0008)$ & 40,53 \\
\hline 70 & & $10,3376(0,0007)$ & 67,54 \\
\hline 75 & & $4,2430(0,0005)$ & 86,68 \\
\hline 80 & & $8,5174(0,0057)$ & 73,25 \\
\hline 85 & & $17,1064(0,0014)$ & 46,28 \\
\hline 90 & & $23,6978(0,0005)$ & 25,58 \\
\hline 105 & & $23,9228(0,0006)$ & 24,87 \\
\hline
\end{tabular}

Keterangan $($ Remarks $):(\mathrm{SD})=$ Standard Deviasi $($ Standart Deviation $)$

Berdasarkan Tabel 7 dan Gambar 14 dapat dilihat, bahwa pada konsentrasi rendah, jumlah adsorbat yang terserap pada adsorben sedikit, sedangkan pada konsentrasi yang lebih tinggi jumlah adsorbat yang terserap pada adsorben semakin banyak. Pada titik kesetimbangan, maka adsorpsi akan menjadi jenuh. Pada konsentrasi yang lebih tinggi lagi, maka jumlah adsorbat yang terserap pada adsorben akan kembali menurun.

\section{Pengaruh waktu kontak}

Setelah didapatkan konsentrasi awal yang optimum, selanjutnya dilakukan variasi waktu kontak untuk melihat pengaruhnya terhadap besarnya efektivitas. Data besarnya efektivitas pada adsorpsi arang aktif batang kersen dengan konsentrasi awal limbah sebesar 31,8432 mg/L (Tabel 7) dan kecepatan pengadukan $150 \mathrm{rpm}$ dapat dilihat pada Tabel 8 .

Dari Tabel 8 dapat dilihat, bahwa pada konsentrasi optimum 31,8432 $\mathrm{mg} / \mathrm{L}$ dan kecepatan pengadukan $150 \mathrm{rpm}$ didapat waktu kontak optimum pada 75 menit., dan pengaruh terhadap besarnya efektivitas dapat dilihat pada Gambar 15.

Penentuan waktu kontak yang menghasilkan kapasitas adsorpsi maksimum pada waktu kesetimbangan adalah sebagai berikut: pada 45 menit pertama adsorpsi yang terjadi belum terlalu banyak dengan efektivitas sebesar $16,51 \%$. Kapasitas adsorpsi terus meningkat sesuai dengan bertambahnya waktu kontak dan berjalan efektif pada waktu kontak, yaitu sebesar 86,68\%.

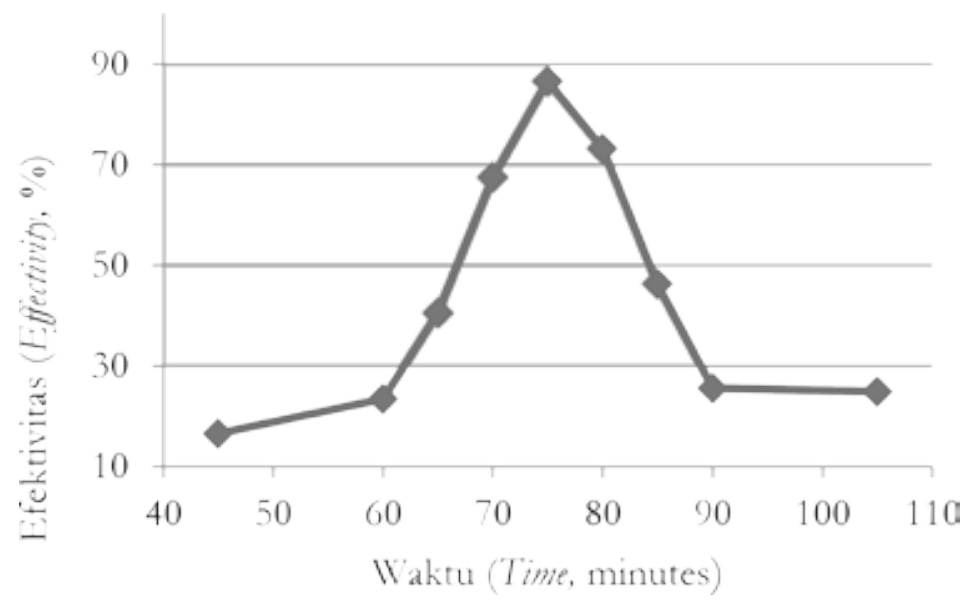

Gambar 15. Grafik kondisi optimum efektivitas daya jerap dengan waktu kontak Figure 15. Graph of optimum condition of adsorption effectivity in relation with contact time 
Tabel 9. Data pada proses adsorpsi dengan variasi kecepatan pengadukan

Table 9. Adsorption process data with speed of stirring

\begin{tabular}{|c|c|c|c|}
\hline \multirow{2}{*}{$\begin{array}{l}\text { Kecepatan Pengadukan } \\
\text { (Speed of Stirring, rpm) }\end{array}$} & \multicolumn{2}{|c|}{$\begin{array}{c}\text { Konsentrasi Hasil Pengukuran } \\
\text { (Concentration of measurement results, } \mathrm{mg} / \mathrm{L} \text { ) }\end{array}$} & \multirow{2}{*}{$\begin{array}{l}\text { Efektivitas } \\
\text { (Effectivity, \%) }\end{array}$} \\
\hline & Awal (Before) & $\begin{array}{c}\text { Akhir (After) } \\
\text { Rerata (Average) }\end{array}$ & \\
\hline 100 & & $6,7827(0,0015)$ & 78,70 \\
\hline 120 & & $5,8162(0,0056)$ & 81,73 \\
\hline 140 & & $5,0018(0,0012)$ & 84,29 \\
\hline 150 & & $4,2430(0,0004)$ & 86,68 \\
\hline 160 & $31,8432(0,0004)$ & $5,2585(0,0004)$ & 83,49 \\
\hline 180 & & $6,3803(0,0002)$ & 79,96 \\
\hline 200 & & $7,3555(0,0012)$ & 76,90 \\
\hline 250 & & 7,5538 (0,0019) & 76,28 \\
\hline 300 & & $7,8613(0,0193)$ & 75,31 \\
\hline
\end{tabular}

Setelah mencapai daya jerap tertinggi, kapasitas adsorpsi akan menurun karena kondisi jenuh, sehingga hampir seluruh permukaan adsorben telah tertutup oleh partikel adsorbat.

3. Pengaruh kecepatan pengadukan

Setelah didapat konsentrasi awal adsorbat dan waktu yang optimum, selanjutnya dilakukan variasi kecepatan pengadukan untuk melihat pengaruhnya terhadap besarnya efektivitas. Data besarnya efektivitas pada adsorpsi arang aktif batang kersen dengan konsentrasi awal limbah $31,8432 \mathrm{mg} / \mathrm{L}$ dan waktu kontak 75 menit (Tabel 8) serta variasi kecepatan pengadukan dapat dilihat pada Tabel 9.

Dari Tabel 9 dapat dilihat, bahwa pada konsentrasi optimum $70 \mathrm{mg} / \mathrm{L}$ dan waktu kontak 75 menit, didapat kecepatan pengadukan optimum sebesar $150 \mathrm{rpm}$. Pengaruh kecepatan pengadukan terhadap besarnya efisiensi adsorpsi arang aktif batang kersen dapat dilihat pada Gambar 16.

Kecepatan pengadukan yang digunakan menentukan kecepatan waktu kontak adsorben dan adsorbat. Pada kecepatan lambat, maka proses adsorpsi berlangsung lambat pula. Kecepatan yang rendah menyebabkan kurang efektifnya tumbukan yang terjadi antar adsorben dan adsorbat, sehingga daya jerapnya bernilai kecil. Pada kecepatan optimum pergerakan partikel menjadi efektif, sehingga adsorben dapat menyerap lebih banyak. Pada kondisi sebaliknya dengan kecepatan pengadukan yang terlalu cepat, maka kemungkinan yang terjadi adalah struktur adsorben menjadi cepat rusak, sehingga proses adsorpsi kurang optimal. Adsorbat yang

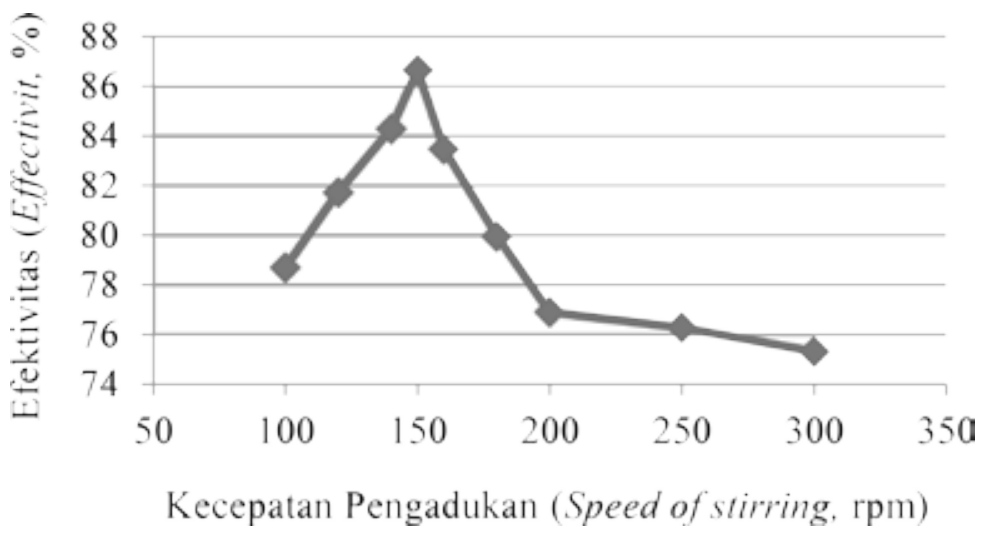

Gambar 16. Grafik kondisi optimum efektivitas daya jerap dengan kecepatan pengadukan Figire 16. Graph of the condition optimum of adsorption effectivity with speed of stirring 
Tabel 10. Data uji biodegradasi

Table 10. Biodegradation test data

\begin{tabular}{|c|c|c|c|c|}
\hline \multirow{3}{*}{$\begin{array}{l}\text { Perlakuan } \\
\text { (Treatment) }\end{array}$} & \multicolumn{3}{|c|}{ Konsentrasi (Concentration, mg/L) } & \multirow{3}{*}{$\begin{array}{c}\text { Efektifitas } \\
\text { (Effectivity, \%) }\end{array}$} \\
\hline & $\begin{array}{c}\text { Krom Total } \\
\text { (Total Chromium) }\end{array}$ & $\begin{array}{c}\text { Krom } \\
(\text { Chromium, VI) }\end{array}$ & $\begin{array}{c}\text { Krom } \\
\text { (Chromium, III) }\end{array}$ & \\
\hline & Rerata & Rerata & Rerata & \\
\hline Sebelum (Before) & $27,2423(0,0001)$ & $0,2865(0,0001)$ & $26,9558(0,0002)$ & \multirow{2}{*}{98,58} \\
\hline Sesudah (After) & $0,6292(0,0001)$ & $0,2475(0,0001)$ & $0,3817(0,0002)$ & \\
\hline
\end{tabular}

telah menempel dan membentuk flok nantinya akan kembali pecah karena besarnya kecepatan pengadukan (Bernard et al., 2013).

\section{Uji Biodegradasi}

Keberadaan krom (VI) yang toksik di perairan atau sungai sebagai akibat kegiatan industri tidak mudah terdegradasi dan dapat membahayakan kesehatan. Uji biodegradasi dilakukan pada limbah yang telah dilakukan adsorpsi pada konsentrasi awal 31,8432 mg/L, waktu kontak 75 menit, dan kecepatan pengadukan $150 \mathrm{rpm}$. Banyaknya krom (VI) menjadi krom (III) oleh bakteri Escherichia coli dapat dilihat pada Tabel 10.

Dari Tabel 10 dapat dilihat bahwa krom (VI) dapat dibiodegradasi menjadi krom (III) oleh Echerichia coli dengan efektivitas sebesar 98,58\%. Proses reduksi krom (VI) yang toksik menjadi krom (III) yang tidak toksik oleh bakteri merupakan sebuah proses detoksifikasi sebagai mekanisme pertahanan diri untuk hidup, dengan membentuk ekstrapolimer yang dapat mengikat logam, mengendapkan logam atau transformasi logam menjadi bentuk yang tidak toksik (Bae et al., 2005).

\section{KESIMPULAN}

Kondisi optimum pembuatan arang aktif kayu kersen dilakukan pada lama aktivasi 70 menit dan tekanan 120 mbar, yang menghasilkan rendemen sebesar 50,7\%, kadar air 0,9\%, kadar zat terbang 9,8\%, kadar abu 6,4\%, kadar karbon terikat $83,8 \%$, daya jerap terhadap iod $912,1 \mathrm{mg} / \mathrm{g}$, daya jerap terhadap metilena biru 218,1 mg/g, dan luas permukaan $808,7 \mathrm{~m}^{2} / \mathrm{g}$. Berdasarkan uji adsorpsi, kondisi optimum yang didapat adalah pada konsentrasi awal adsorbat $70 \mathrm{mg} / \mathrm{L}$, waktu kontak 75 menit, kecepatan pengadukan 150, rpm dan efektivitas yang didapat sebesar
86,68\%. Efektivitas biodegradasi krom (VI) menjadi krom (III) oleh bakteri Escherichia coli adalah sebesar $98,59 \%$.

\section{KONTRIBUSI PENULIS}

Ide, desain dan rancangan percobaan dilakukan oleh ESL,YSH dan GP. Pengambilan data dilakukan oleh ESL,YSH dan GP. Analisis data dilakukan oleh ESL,YSH dan GP. Penulisan manuskrip dilakukan oleh ESL,YSH dan GP. Perbaikan dan finalisasi manuskrip dilakukan oleh ESL,YSH dan GP.

\section{DAFTAR PUSTAKA}

Bae WC, Lee HK, Choe YC, Jahng DJ, Lee SH, Kim SJ, Lee JH, \& Jeong BC. (2005). Purification and characterization of NADPH-dependent $\mathrm{Cr}(\mathrm{VI})$ reductase from Escherichia coli ATCC 33456. Journal of Microbiology, 43(1), 21-7.

Bernard E, Jimoh A, Odigure JO. (2013). heavy metals removal from industrial waste water by activated carbon prepared from coconut shell. Research Journal of Chemical Sciences, 3(8), 3-9.

Burg R, \& Liu D, (1993). Chromium and hexavalent chromium. Journal of Applied Toxicology, 13(3), 225-230, doi: 10.1002/ jat. 2550130315.

Hartoyo. (1974). Arang aktif pembuatan dan kegunaannya. Kehutanan Indonesia Volume I Januari, Bogor.

Hartoyo, Hudaya, N. \& Fadli. (1990). Pembuatan arang aktif dari tempurung kelapa dan kayu bakau dengan cara aktivasi uap. Jurnal Penelitian Hasil Hutan, (8)8-16. 
Hendra D. (2007). Pembuatan arang aktif dari limbah pembalakan kayu puspa dengan teknologi produksi skala semi pilot. Jurnal Penelitian Hasil Hutan, 25(2), 93-107.

Menteri Lingkungan Hidup. (2014). Peraturan Menteri Lingkungan Hidup No. 5 tahun 2014 tentang baku mutu air limbah. Jakarta

Morton J. (1987). Jamaica cherry Muntingia calabura L. fruits of warm climates. Miami, Florida, Amerika Serikat. Diakses dari http:// www.hort.purdue.edu/newcrop /morton/ jamaica, cherry.html, pada 9 Januari 2016.

Pari G. (2004). Kajian struktur arang aktif dari serbuk. gergaji kayu sebagai adsorben emisi formaldehida kayu lapis. (Disertasi doktor). Institute Pertanian Bogor, Bogor.

Pari G, Djeni H. \& Ridwan AP. (2008). Peningkatan mutu arang aktif kulit kayu mangium. Jurnal Penelitian Hasil Hutan, 26(3), 214-227.

Prastiwi D.A. (2013). Pemanfaatan arang aktif sebagai carrier unsur hara mikro dalam pembuatan pupuk lambat tersedia. (Tesis Master). Institut Pertanian Bogor, Bogor.
Rumidatul A. (2006). Efektivitas arang aktif sebagai adsorben pada pengolahan air limbah. (Tesis Master). Institut Pertanian Bogor, Bogor

Schukin L.I., Kornnievich M.V. Vartapetjan R.S, \& Beznisko. S.I. (2002). Low temperature plasma oxidation of activated carbons. UK : Elsevier

Skoog DA, James H, Timothy AN. (1998). Principle of instrumental analysis. Fifth Edition. Florida USA: Harcourt Brace \& Company.

Standar Nasional Indonesia. (1995). (SNI 063730-1995). Arang Aktif Teknis. Badan Standardisasi Nasional, Jakarta.

Standar Nasional Indonesia. (2004). (SNI 066989.17-2004). Uji Krom Total Dalam Air dan Air Limbah. Badan Standardisasi Nasional, Jakarta.

Standar Nasional Indonesia. (2009). (SNI 6989.71-2009). Air dan Air Limbah. Badan Standardisasi Nasional, Jakarta. 
